Article

\title{
Glacial Lake Inventory Derived from Landsat 8 OLI in 2016-2018 in China-Pakistan Economic Corridor
}

\author{
Da Li ${ }^{1,2}$, Donghui Shangguan ${ }^{1, *(\mathbb{D})}$ and Muhammad Naveed Anjum ${ }^{1}(\mathbb{D}$ \\ 1 State Key Laboratory of Cryospheric Science, Northwest Institute of Eco-Environment and Resources, \\ Chinese Academy of Sciences, Lanzhou 730000, China; lida@lzb.ac.cn (D.L.); naveedwre@lzb.ac.cn (M.N.A.) \\ 2 University of Chinese Academy of Sciences, Beijing 100049, China \\ * Correspondence: dhguan@lzb.ac.cn
}

Received: 11 March 2020; Accepted: 22 April 2020; Published: 1 May 2020

\begin{abstract}
The China-Pakistan Economic Corridor (CPEC), a key hub for trade, is susceptible to glacial lake outburst floods. The distributions and types of glacial lakes in the CPEC are not well documented. In this study, cloud-free imagery acquired using the Landsat 8 Operational Land Imager during 2016-2018 was used to delineate the extent of glacial lakes in the mountainous terrain of the CPEC. In the study domain, 1341 glacial lakes (size $\geq 0.01 \mathrm{~km}^{2}$ ) with a total area of $109.76 \pm 9.82 \mathrm{~km}^{2}$ were delineated through the normalized difference water index threshold method, slope analysis, and a manual rectification process. On the basis of the formation mechanisms and characteristics of glacial lakes, four major classes and eight subclasses of lakes were identified. In all, 492 blocked lakes (162 end moraine-dammed lakes, 17 lateral moraine-dammed lakes, 312 other moraine-dammed lakes, and 1 ice-blocked lake), 723 erosion lakes (123 cirque lakes and 600 other erosion lakes), 86 supraglacial lakes, and 40 other glacial lakes were identified. All lakes were distributed between 2220 and $5119 \mathrm{~m}$ a.s.l. At higher latitudes, the predominate lake type changed from moraine-related to erosion. From among the Gez, Taxkorgan, Hunza, Gilgit, and Indus basins, most glacial lakes were located in the Indus Basin. The number and area of glacial lakes were larger on the southern slopes of the Karakoram range.
\end{abstract}

Keywords: glacial lake; inventory; CPEC; Karakoram; remote sensing

\section{Introduction}

A glacial lake is a lake in a cold region that is near or in contact with a glacier, or that is developing through recent glacial morphology [1]. Many glacial lakes are unstable, and their sudden bursting can cause devastating floods, known as glacial lake outburst floods (GLOFs), in cryospheric regions such as the northern parts of the China-Pakistan Economic Corridor (CPEC). To the year 2000, over 30 GLOF events had been recorded in the Hunza Basin (a sub-basin of the Indus River in the CPEC covering 22,000 $\mathrm{km}^{2}$ ) alone [2]. Recent research has revealed that the occurrence of GLOFs has rapidly increased over the past two decades [3]. However, glacial lake inventories, evaluations of GLOF risks, and investigations of the physical geographic conditions have not been well developed for this disaster-prone region.

Glacial lake inventories have been compiled for many other areas such as the central Tibet Plateau [4,5], southern margin of the Himalayas [1,6-12] and Tianshan [13,14]. Many of them have contributed to disaster risk assessment and provided strong evidence of regional climate change. Information on the characteristics of glacial lakes is vital for the formulation of pertinent policy at local government levels and the mitigation of potential GLOF-induced risks $[1,15,16]$. Therefore, a glacial lake inventory as well as a study of geographical vulnerabilities of GLOFs in the CPEC are urgently required. 
The aim of this study was to provide a comprehensive and systematic glacial lake inventory for the CPEC using Landsat 8 Operational Land Imager (OLI) data acquired during 2016-2018. We anticipate that this inventory will provide basic information on glacial lakes in the CPEC and raise awareness of glacial lakes in central Asia. We also hope that the inventory may reduce risks and losses caused by disasters related to glacial lakes.

\section{Study Region}

The CPEC is situated at border areas amidst China, Pakistan, Afghanistan, Tajikistan, and India but mainly comprises the western part of Xinjiang Uygur Autonomous Region in China and the whole of Pakistan. A major portion of the mountainous areas of the CPEC, which include the Kunlun, Pamir, Himalaya, Karakoram, and Hindukush ranges, is regarded as a region of perennial snow and glaciers (Figure 1). Among these ranges, the largest and most concentrated distribution of glacial lakes is located in the Pamir and Karakoram mountains. The Karakoram Highway (KKH), built to connect China and Pakistan, crosses these high mountain ranges and a region containing numerous glacial lakes (Kashgar to Thakot). In this investigation, five basins along the KKH (the Gez, Taxkorgan, Hunza, Gilgit, and Indus river basins) between Kashgar and Thakot were selected. The estimated total area of these basins is approximately $167,000 \mathrm{~km}^{2}$, with an average altitude of $4135 \mathrm{~m}$ a.s.l.

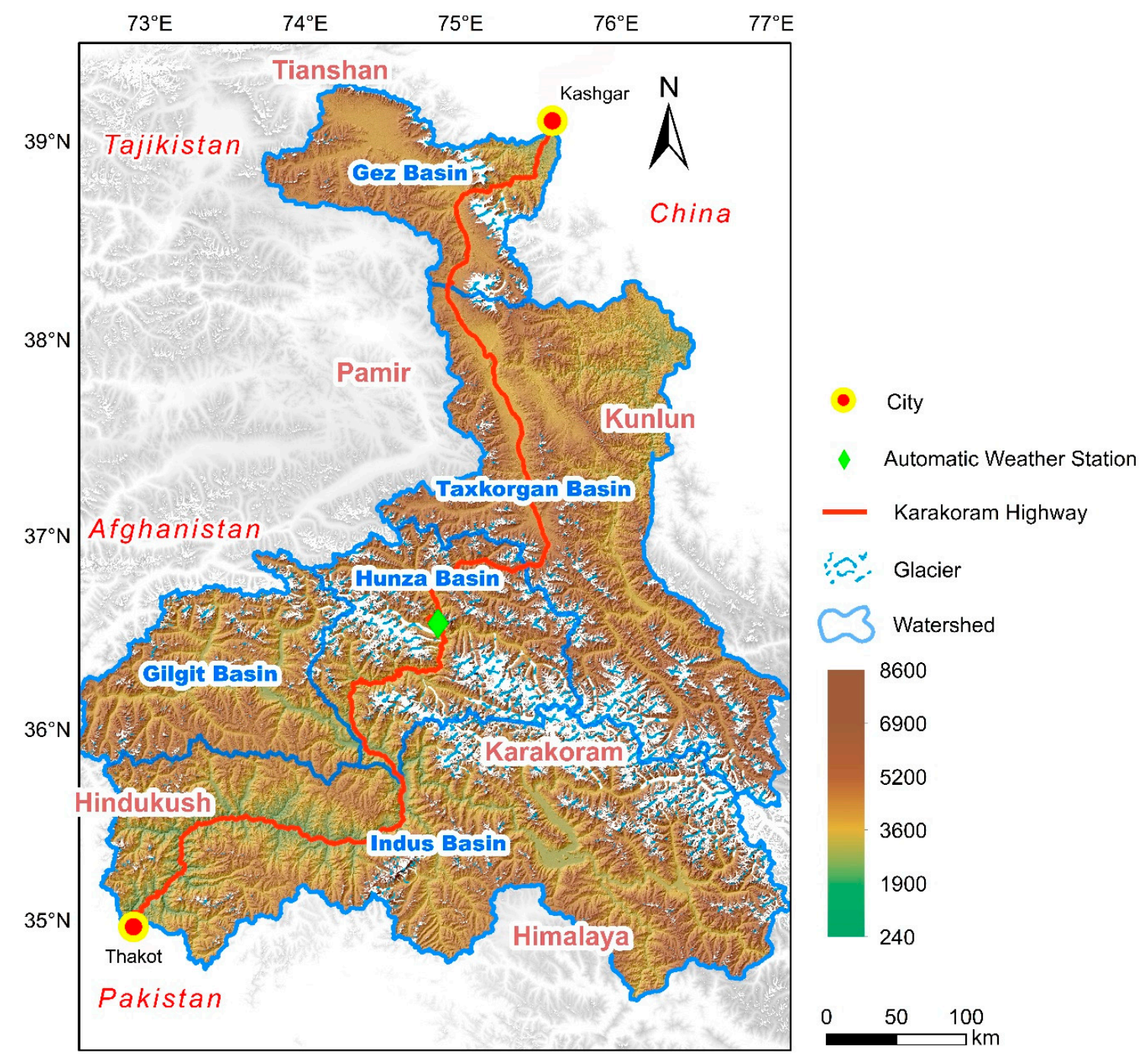

Figure 1. Location of the study area and boundaries of the five river basins. In the figure, digital 
elevation model data come from Advanced Spaceborne Thermal Emission and Reflection Radiometer Global Digital Elevation Model Version 2 (ASTER GDEM V2). Basin boundaries are delineated based on ASTER GDEM V2 through ArcSWAT tool. Glacier data are Randolph Glacier Inventory 6.0. The Karakoram Highway are delineated from Google Earth.

In the study region, glaciers are widely distributed in the western Kunlun and Karakoram mountains. Recent glacier studies have revealed that most of the glaciers in the Karakoram are more stable than those in the Tianshan and southern slopes of the Himalayas, where glaciers have substantially retreated $[17,18]$. In the Karakoram range, there are numerous large valley glaciers with lengths longer than $40 \mathrm{~km}$, such as the Batura glacier $(59 \mathrm{~km})$, Baltoro glacier $(63 \mathrm{~km})$, and Hispar glacier $(54 \mathrm{~km})$, according to Randolph Glacier Inventory 6.0. The large surface areas of these glaciers create a favorable environment for supraglacial lakes. Furthermore, studies have reported the existence of many surge-type glaciers in the Karakoram range [19]. These surge-type glaciers are originating factors for many types of blocked lakes and GLOFs.

The climate of the study area is cold and dry, with an annual average temperature of $9{ }^{\circ} \mathrm{C}$ (Ghulkin automatic weather station, $74.8706^{\circ} \mathrm{E}, 36.4215^{\circ} \mathrm{N}, 2726 \mathrm{~m}$ a.s.l. from May 2018 to May 2019, Figure 1). It is a typical alpine climate area mainly affected by westerly circulation. Although temperature gradually rises from north to south, the alpine characteristics of the mountains, cold and dry, remain obvious in the southern parts of the study region. The Karakoram seasonal cycle is dominated by nonmonsoonal winter precipitation, and water inputs concentrate in winter months [20,21]. Although annual average precipitation as measured by our automatic weather station is less than $200 \mathrm{~mm}$ in the valley, a large difference exists in the amount of precipitation between the upper mountains and downhill [22]. In the glacier accumulation areas, large amounts of precipitation result in giant glaciers.

\section{Input Data}

Because of the remote locations of glacial lakes, the most accessible means to acquiring data of their positions and areas is with remote sensing images. Satellite Landsat 8, launched in 2013, offers remote sensing images with a spatial resolution of up to $15 \mathrm{~m}$ in panchromatic imaging mode and $30 \mathrm{~m}$ in multispectral imaging mode; it is fully suitable for extracting glacier lake data. In this study, fourteen Landsat 8 OLI terrain-corrected images (Level 1TP, from https://glovis.usgs.gov/) collected during July to October of 2016, 2017, and 2018 were selected. To improve the accuracy of glacial lake outline delineation, image selection criteria were set as follows: (1) cloud covered less than $10 \%$ of the image; (2) its acquisition time was during the end of the glacier ablation season; and (3) it did not contain snow. These criteria were used because first, cloud cover can block spectrum signals reflected from the earth's surface; second, during the ablation season, glacial lakes are at their maximum extents-thus, only satellite data acquired later than July was considered; and third, snow with a high albedo can blur boundaries between lakes and snow-covered land, and snowfall is often accompanied by a temperature drop that could cause lakes, especially smaller lakes, to partially freeze. With these criteria, obtaining high-quality images of the CPEC within a single year proved difficult, so images from 2016 to 2018 were considered. Details of the images used are provided in Table 1. 
Table 1. Multispectral satellite imagery used in the study.

\begin{tabular}{ccc}
\hline Sensor & Path/Row & Date \\
\hline & $148 / 35$ & $2016 / 09 / 24$ \\
$148 / 36$ & $2017 / 10 / 29$ \\
$149 / 33$ & $2018 / 07 / 19$ \\
$149 / 34$ & $2016 / 10 / 01$ \\
Landsat 8 OLI & $149 / 35$ & $2016 / 10 / 01$ \\
& $149 / 36$ & $2017 / 10 / 04$ \\
& $150 / 33$ & $2017 / 09 / 09$ \\
& $150 / 34$ & $2017 / 09 / 09$ \\
& $150 / 35$ & $2017 / 09 / 09$ \\
& $150 / 36$ & $2017 / 10 / 27$ \\
& $151 / 33$ & $2018 / 07 / 17$ \\
& $151 / 34$ & $2016 / 10 / 15$ \\
& $151 / 35$ & $2016 / 10 / 15$ \\
& $151 / 36$ & $2016 / 10 / 15$ \\
\hline
\end{tabular}

In addition to the Landsat images, Advanced Spaceborne Thermal Emission and Reflection Radiometer Global Digital Elevation Model Version 2, which is provided by the US Geological Survey (https://earthexplorer.usgs.gov/) and has a spatial resolution of up to $30 \mathrm{~m}$, was utilized to analyze slope conditions in the study domain. Google Earth was also utilized to identify types of glacial lakes.

\section{Methods}

\subsection{Glacial Lake Mapping}

The outlines of glacial lakes were delineated using semiautomatic mapping methods [23-25]. First, the normalized difference water index (NDWI) (1) [23], which is an established band ratio method employed for water body extraction, was used to delineate lakes. Slope analysis was then used to eliminate terrain impact. Finally, manual work was undertaken to examine lake characteristics and rectify mistakes in the original NDWI based delineation.

The NDWI is defined as

$$
\mathrm{NDWI}=(\text { Blue }- \text { SWIR }) /(\text { Blue }+ \text { SWIR }),
$$

where Blue and SWIR are blue band and short-wave infrared band respectively.

Various band combinations have been used for recognition tasks with differing geographical backgrounds [26,27]. In this inventory, blue (Landsat OLI band 2) and SWIR (Landsat OLI band 6) bands were chosen. Testing indicated that thresholds of $0.2-0.8$ performed well in representing all water bodies in the CPEC.

The CPEC is a concentrated distribution area of high mountain ranges, and images of the region frequently contain large shadow areas. Due to the spectral similarity between water bodies and shadows, distinguishing them by applying only the band ratio method (NDWI) is challenging. Fortunately, because lakes are flat, slope analysis $\left(<10^{\circ}\right)$ helped eliminate shadow disturbance.

Manual work was essential after NDWI calculation and slope analysis. First, glacial lakes with their differing depths, turbidity, and status vary widely in spectral characteristics, and setting a precise NDWI threshold to extract all glacial lakes is impossible. The threshold was therefore set loosely to avoid gaps and omissions. With the loose threshold, many nonlake surface features were misclassified as lakes, and manual work helped rectify this outcome. Second, water bodies in the CPEC are not limited to glacial lakes; other water bodies (e.g., rivers, reservoirs) are also nestled in the study domain. Manual work helped differentiate the bodies. Almost all the postprocessing work involved manual visual interpretation that was extremely time consuming [28]. 
Figure 2 shows the results of each delineation step. The threshold of NDWI is available to extract all water bodies (b), and the slope analysis is an effective measure to eliminate and reduce shadow interference (c). Obviously, through manual correction, a good result is made in accuracy improvement as well $(\mathrm{d})$.
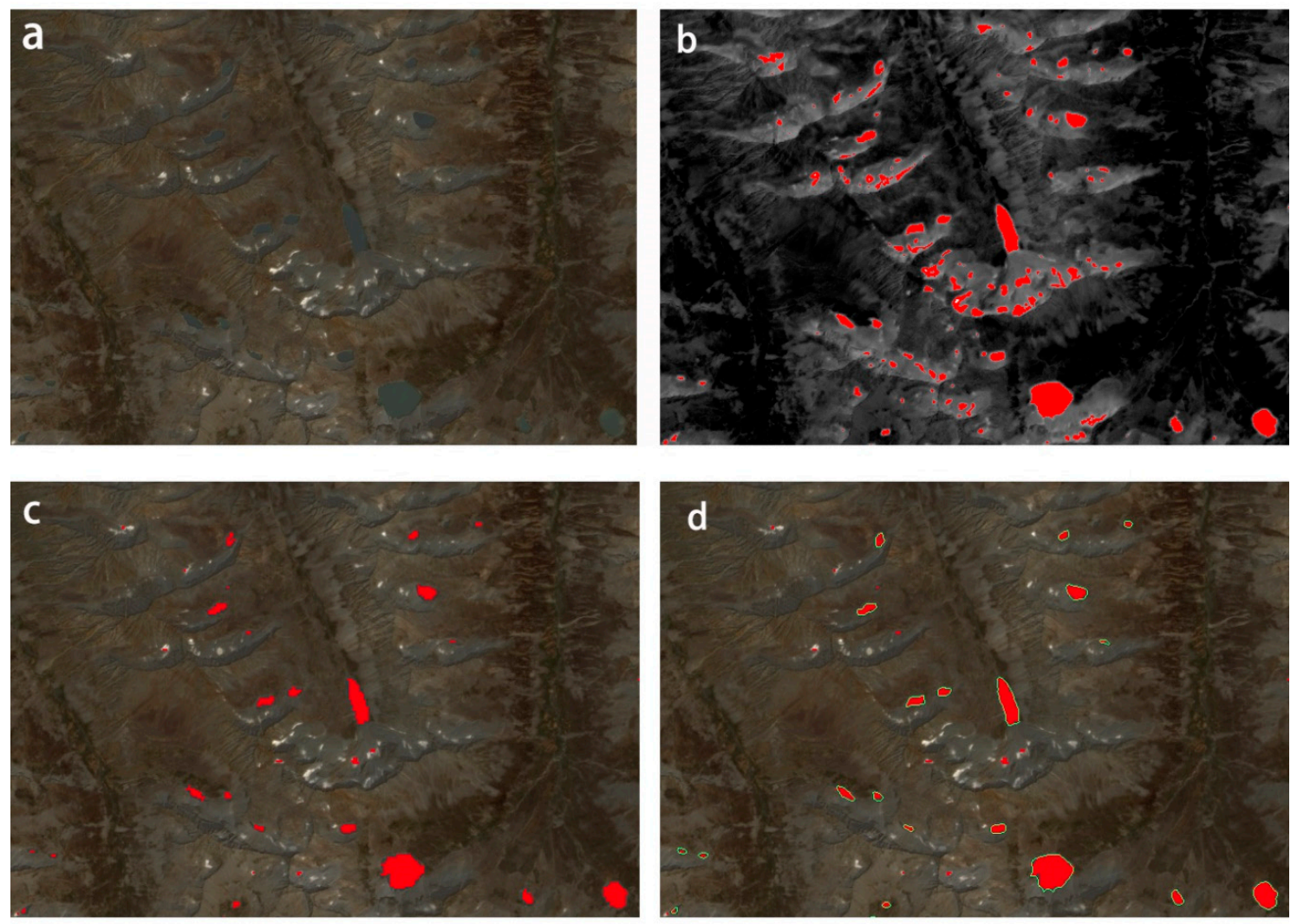

Figure 2. Results of each delineation step. (a) An original image. (b) A NDWI result with threshold (0.2-0.8) fulfilled areas (in red). (c) The result of slope analysis, which erases the areas with slopes greater than 10 degrees. In (d), green outlines are the lake outlines after manual correction process, and red area are the same result as (c).

\subsection{Glacial Lake Definition and Classification}

A glacial lake may be defined as a lake in a cold region that is near or in contact with a glacier or is developing through recent glacial morphology [1]. However, the definition is controversial [29]. Although similar definitions of 'glacial lake' in various inventories have been presented, a consensus on specific rules for glacial lake extraction has not been reached. Researchers often formulate series of limitations based on their research purposes and the geographical conditions of their study area. Some researchers have emphasized the relationship between glacial lakes and glaciers, stating that only water bodies within $10 \mathrm{~km}$ of a glacier should be considered glacial. Others have argued that lakes with an elevation higher than $3000 \mathrm{~m}$ a.s.l. can be recognized as glacial [12,30]. Other researchers have posited that the lake formation mechanism should be the criteria, where lakes within a glaciation area can be considered glacial $[1,28]$. In this study, we wanted to create an inventory based on the geographical conditions of the CPEC and aimed to provide both a basic data set of glacial lakes and information enabling progress in GLOF risk assessment. The definition that the lake is in a cold region and near or in contact with a glacier or is developing through recent glacial morphology [1] was chosen for these ends. Because the entire study area is a Quaternary glaciation region [31], the inventory includes all natural lakes in the study region as glacial lakes, with no limitations regarding elevation or distance. 
Because geographical environments vary, types of glacial lake that illustrate lake characteristics have been described [1]. Two main classifications of glacial lake have arisen. One is based on the relationship between the lake and the glacier or glaciers [12,29,32]. Another is defined based on the lake's formation mechanism [1,33]. In the first classification, glacial lakes are divided into categories such as glacial-fed and non-glacial-fed lakes, supraglacial and proglacial lakes, connected and unconnected lakes according to their hydraulic connection and spatial position $[12,34,35]$. In the other classification, glacial lakes are typified as erosion lakes (including cirque, valley, and erosion lakes), moraine-dammed lakes (end moraine-dammed lakes, lateral moraine-dammed lakes), supraglacial lakes, and blocked lakes (fed mainly by glacier meltwater), among others. The glacial lakes classification system used in this study is based on formation mechanisms because these mechanisms provide additional information about lakes that is especially relevant to GLOFs. For example, erosion lakes are more stable than moraine-dammed lakes [36], and because of their relatively stable topographic and geological state, resources should be concentrated on those with higher GLOF risks. Because a disaster risk assessment process would be a substantial, meaningful step in CPEC development, integrating and utilizing a formation mechanism-based glacial lake classification system is desirable. Yao et al. built a formation mechanism-based glacial lake classification system [29] that provides a good reference. In this study, we categorized in situ glacial lakes into four classes and eight subclasses. Considering the geographical conditions of the CPEC, some classes (such as moraine thaw lakes) were removed from their classification system. Table 2 provides details of our classification. Google Earth, with its high-resolution images and three-dimensional views, was used to obtain information about lakes and to help in determining lake types.

Table 2. Glacial lake classification.

\begin{tabular}{|c|c|c|}
\hline \multicolumn{2}{|c|}{ Lake Type } & \multirow{2}{*}{ Definition } \\
\hline Class & Subclass & \\
\hline \multirow{4}{*}{ Blocked lakes } & $\begin{array}{l}\text { End moraine-dammed } \\
\text { lakes }\end{array}$ & $\begin{array}{l}\text { Lakes blocked by an end moraine; located in front of } \\
\text { the mother glacier and supplied by the glacier }\end{array}$ \\
\hline & $\begin{array}{l}\text { Lateral } \\
\text { moraine-dammed lakes }\end{array}$ & $\begin{array}{l}\text { Lakes blocked by lateral moraines located at both } \\
\text { sides of the dam-forming glacier; its water supply is } \\
\text { the dam-forming glacier }\end{array}$ \\
\hline & $\begin{array}{l}\text { Other moraine-dammed } \\
\text { lakes }\end{array}$ & $\begin{array}{l}\text { There are two other types of moraine-dammed lake: } \\
\text { (1) lake developing on the moraine, mostly formed by } \\
\text { the thawing of ice and typically situated on the end } \\
\text { moraine of a modern glacier; and (2) lakes blocked by } \\
\text { a moraine coming from a tributary valley glacier [37] }\end{array}$ \\
\hline & Ice-blocked lakes & $\begin{array}{l}\text { Lakes blocked by glacier ice; usually related to glacial } \\
\text { advance }\end{array}$ \\
\hline \multirow[t]{2}{*}{ Erosion lakes } & Cirque lakes & $\begin{array}{l}\text { Lakes located in a cirque and mainly caused by } \\
\text { glacial retreat; typically supplied by a modern glacier } \\
\text { but includes lakes located in an ancient cirque } \\
\text { without a glacier }\end{array}$ \\
\hline & Other erosion lakes & Erosion lakes other than cirque lakes \\
\hline Supraglacial lakes & & $\begin{array}{l}\text { Lakes located on the surface of a glacier; caused by } \\
\text { differential ablation of the glacier surface or affected } \\
\text { by poor drainage of internal glaciers [36] }\end{array}$ \\
\hline Other glacial lakes & & $\begin{array}{l}\text { Lakes in glaciation areas; blocked by geological } \\
\text { hazard such as landslide, rockfall, or debris flow [33] }\end{array}$ \\
\hline
\end{tabular}

\subsection{Glacial Lake Coding}

Consulting the glacier coding system formulated by the National Snow and Ice Data Center, we developed the following glacial lake coding: ' $X X n n n n n N m m m m m m E^{\prime}$ (' $X X$ ' is an abbreviation of the lake type and 'nnnnn' is the centroid latitude value of the lake multiplied by 100000 ; similarly, 
'mmmmmmm' represents the longitude, beginning with ' 0 ' if the longitude value is less than 100 ; ' $N$ ' and ' $E$ ' mean north and east, respectively).

To assess potential GLOF risk, distances form end moraine-dammed lakes to their nearby structures were calculated. Threatening levels of the lakes were also given as attributions to the inventory data set.

\subsection{Uncertainty}

In satellite imagery interpretation, studies have reported that the interpretation of mixed pixels can cause uncertainty in glacial lake delineation [38,39]. A distance of \pm 0.5 pixels has been regarded a proper range to represent this uncertainty [40-42]. Therefore, a buffer with a distance of a half-pixel outside the boundaries was adopted to appraise uncertainty (2).

$$
\text { Uncertainty }=(\mathrm{P} / 2 \times \mathrm{C}) / \mathrm{S} \text {, }
$$

where $P$ is the pixel length, $C$ is the circumference, and $S$ is the area of glacial lakes.

Because $P$ is a fixed value, errors are dominated by the ratio of the lake's circumference and area. Table 3 displays the mean uncertainty for various lake scales.

Table 3. Uncertainty.

\begin{tabular}{cc}
\hline Lake Scale $\left.\mathbf{( k m}^{\mathbf{2}}\right)$ & Uncertainty $\mathbf{( \% )}$ \\
\hline $0.01-0.03$ & 0.22 \\
$0.03-0.05$ & 0.16 \\
$0.05-0.07$ & 0.13 \\
$0.07-0.09$ & 0.11 \\
$0.09-0.11$ & 0.10 \\
$0.11-0.2$ & 0.08 \\
$0.2-0.5$ & 0.06 \\
$0.5-$ & 0.03 \\
\hline
\end{tabular}

The uncertainty of the mapping varies by scale: as the scale increases, uncertainty decreases. The smaller a glacial lake is, the greater its uncertainty. Therefore, a minimum area of $0.01 \mathrm{~km}^{2}$ was set as the threshold, which means water bodies with an area smaller than $0.01 \mathrm{~km}^{2}$ (approximately 10 pixels in original OLI image resolution) were eliminated after lake mapping to improve accuracy. Overall, the mean uncertainty of the total glacial lake mapping is $8.95 \%$, which may ensure credibility and reliability.

In addition, some uncertainty comes from the subjective discrimination of ground objects by researchers, which is unavoidable in manual rectification. In the present study, lake delineation was achieved through a semiautomatic method, and nearly every glacial lake experienced manual rectification. Uncertainty appears in any subjective process, and it should be evaluated; however, no appropriate, quantifiable uncertainty estimation for this type of manual rectification process exists. To improve the inventory's credibility and validity, rechecking work was conducted after delineation, mainly through examining target lakes on high-resolution images provided by Google Earth and field investigation data. We believe that the level of accuracy of the glacial lakes inventory along the CPEC can satisfy the requirements of disaster prevention projects and investigations of geographical elements.

\section{Results}

\subsection{Number and Area of Glacial Lakes}

In total, 1341 glacial lakes ranging from 0.01 to $7.20 \mathrm{~km}^{2}$, with an accumulated area of $109.76 \pm$ $9.82 \mathrm{~km}^{2}$ are delineated in this inventory. The mean lake area is approximately $0.08 \mathrm{~km}^{2}$. Nine lakes are larger than $1.00 \mathrm{~km}^{2}$. Karakul Lake, located at the west slope of Mt. Kongur, is the largest, with an area of $7.20 \mathrm{~km}^{2}$. 
Glacial lakes with an area less than $0.03 \mathrm{~km}^{2}$ account for almost half of all lakes (Figure 3), but these small lakes account for only $10.6 \%$ of the total lake area. Glacial lakes larger than $0.20 \mathrm{~km}^{2}$ comprise $6.1 \%$ of the number but $49.4 \%$ of the total area.

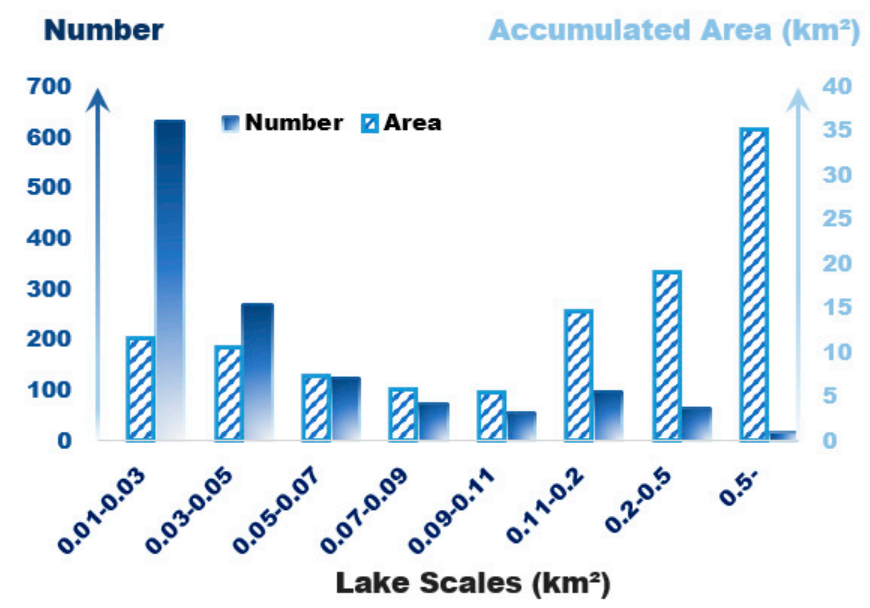

Figure 3. Number and accumulated area of glacial lakes at various scales.

Regarding glacial lake type (Figure 4), 723 erosion lakes (cirque lakes and other erosion lakes) with a total area of $54.27 \mathrm{~km}^{2}$ were identified. This type accounts for approximately half the total number and half the total area. Lateral moraine-dammed lakes and ice-blocked lakes have the lowest number, 17 and 1, respectively. In addition, the relationship between quantity and area of glacial lakes varies by lake type. Forty lakes (only $2.9 \%$ of the total) are of other types (far fewer than erosion lakes), but their collective area of $16.4 \mathrm{~km}^{2}$ represents $14.9 \%$ of the total area. Lake area is related to lake type. Lakes of the 'other glacial lake' type have an average area of $0.41 \mathrm{~km}^{2}$, which is far larger than the overall average $\left(0.08 \mathrm{~km}^{2}\right)$. Finally, 86 supraglacial lakes were identified. They have a total area of only $1.83 \mathrm{~km}^{2}$, and their mean area is $0.02 \mathrm{~km}^{2}$, far smaller than the average.

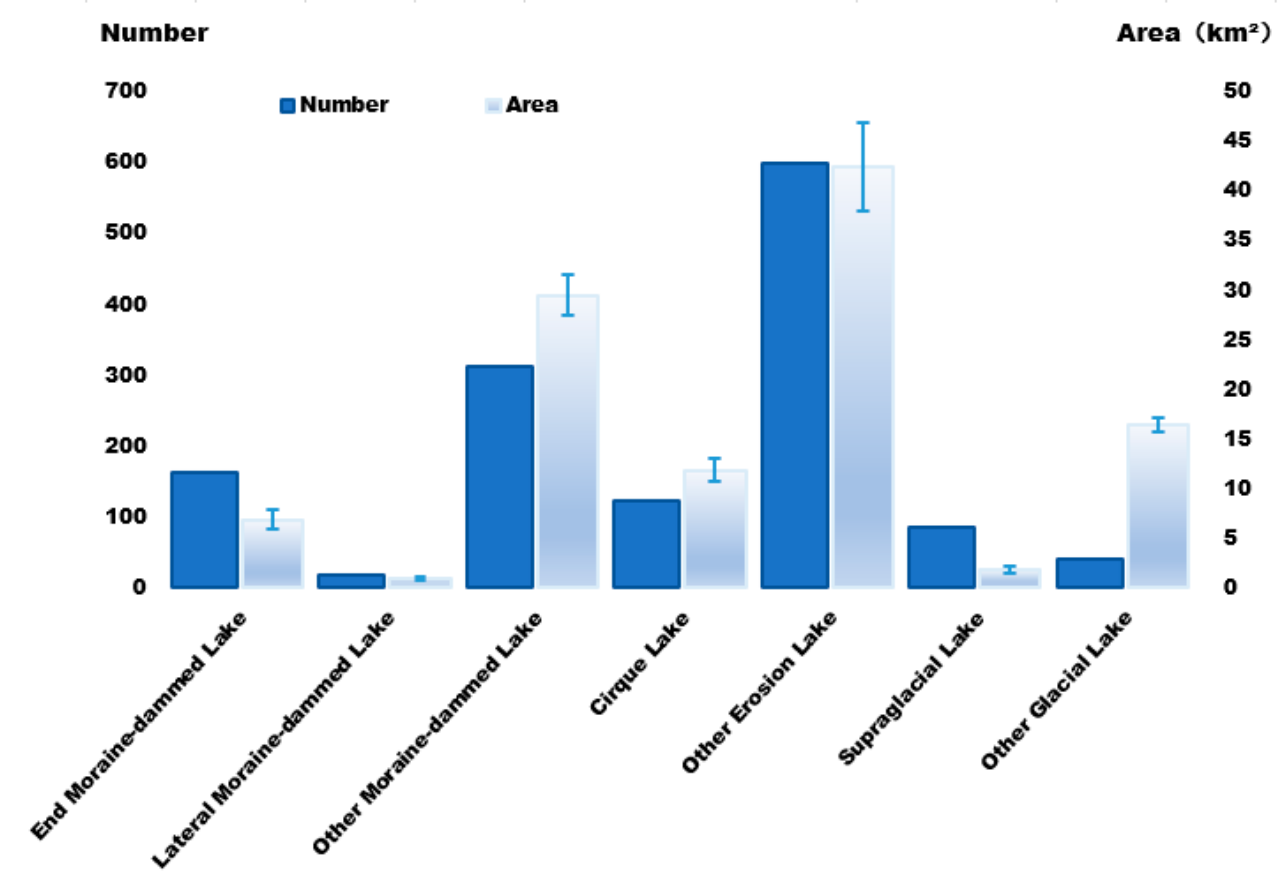

Figure 4. Number and area of different glacial lake types. Glacial lakes are classified into eight subclasses (Table 2), and this figure presents the number and area of each subclass except ice-blocked lakes. 


\subsection{Spatial Distribution of Glacial Lakes in the CPEC}

To analyze the spatial distribution of glacial lakes in the CPEC, the five river basins were divided into sub-basins using the ArcSWAT tool. The threshold area for sub-basins was selected as $1000 \mathrm{~km}^{2}$. Figure 5 displays the boundaries of the basins and their sub-basins. Then, the percentage of lake area (PLA), which represents glacial lake area per square kilometer, was used as a parameter to illustrate the spatial distribution of glacial lakes.

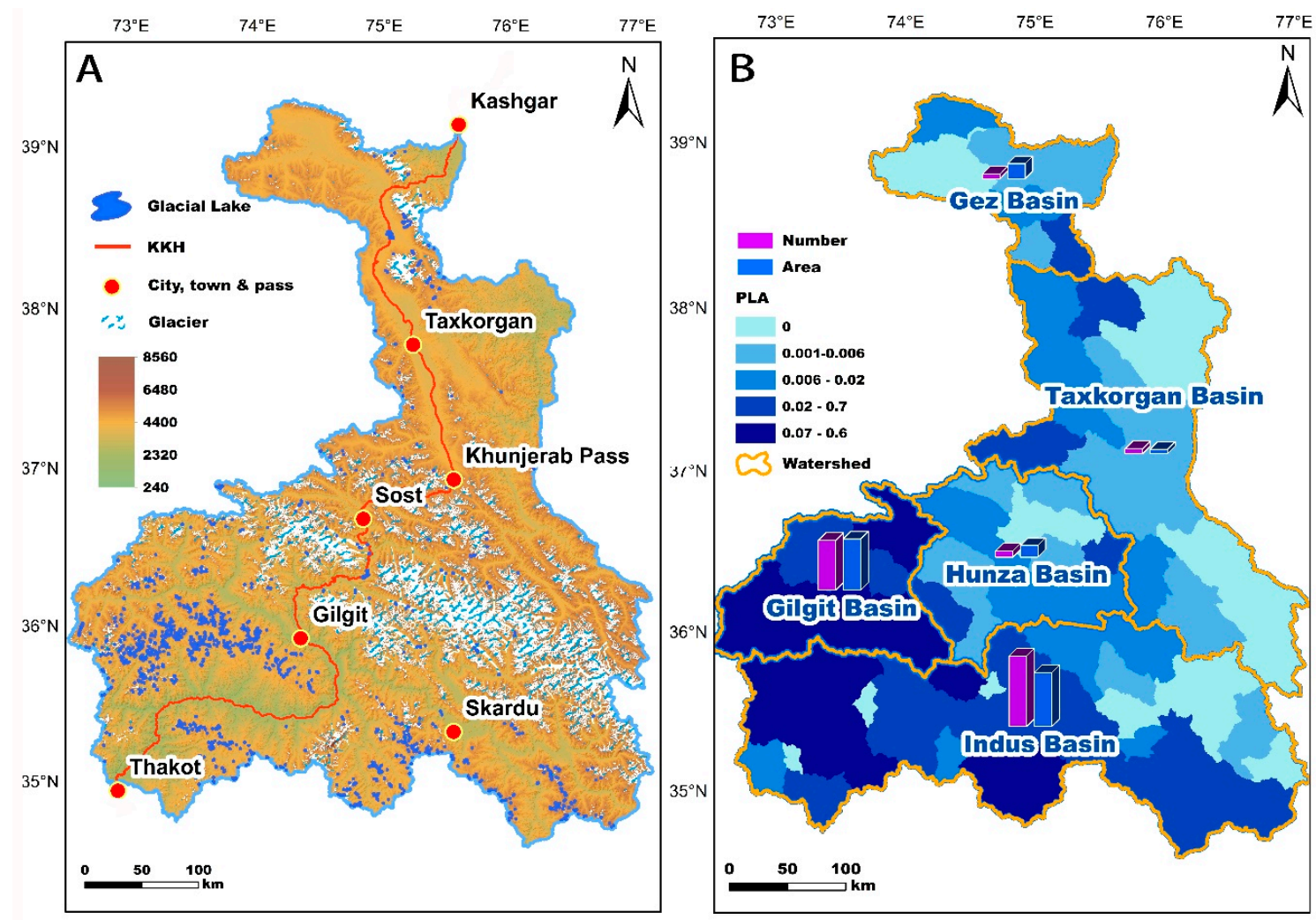

Figure 5. Locations of glacial lakes (A) and glacial lake area in different water basins (B). The values of the percentage of lake area (PLA), glacial lake area per square kilometer, of sub-basins are shown (B). Bars of number and area are statistical results for basins (e.g., Hunza, Gilgit).

Generally, the results exhibit a decreasing tendency from south to north. Almost all sub-basins with high PLA values are located in the Gilgit and Indus basins. Southern sub-basins in the Gez and central sub-basins in the Hunza have quite high PLA values. This is because of the distribution of enormous lakes such as Karakul Lake in the southern Gez basin and Attabad Lake in the central Hunza Basin; in fact, few glacial lakes were identified in either of these basins.

Lake types in five basins were analyzed (Figure 6). Except for ice-blocked lakes, all types of glacial lakes are distributed in all the basins. Obvious differences were observed in the distribution characteristics of the basins as follows: (1) erosion lakes, the most numerous type, are mainly distributed in the Gilgit and Indus basins; (2) supraglacial lakes are relatively concentrated in the Hunza Basin; and (3) moraine-related blocked lakes dominate in the Gez and Taxkorgan basins. Moving south, the predominant lake type transformed from moraine-related to erosion. 


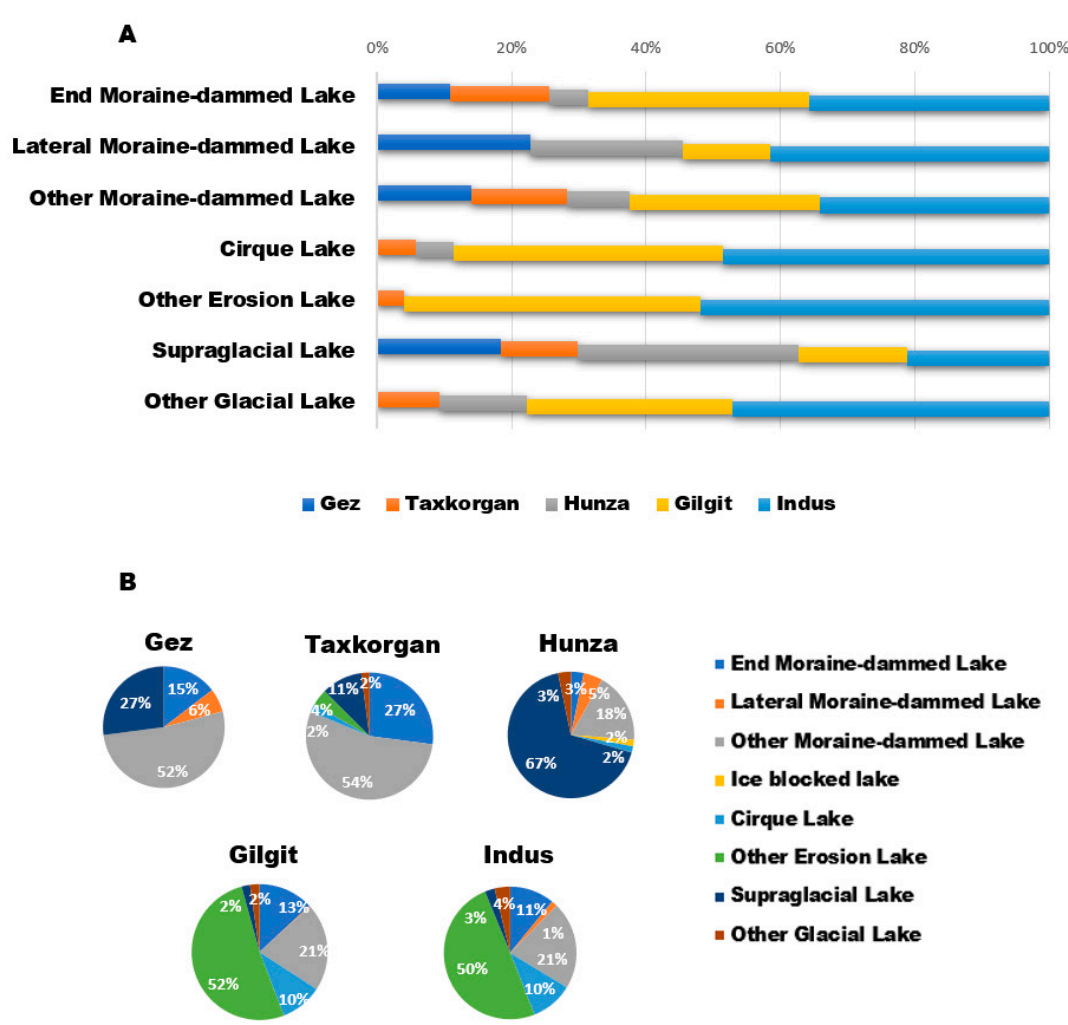

Figure 6. Spatial distribution of different types of glacial lakes (A) and glacial lake composition of the five basins (B).

\subsection{Distribution of Glacial Lakes by Elevation}

The distribution of glacial lakes at different elevation bands is demonstrated in Figure 7. All the glacial lakes are located between 2220 and $5119 \mathrm{~m}$ a.s.l., and almost half are concentrated between 4100 and $4500 \mathrm{~m}$ a.s.l. Generally, the variation tendencies of area and number were similar as elevation changes. Both the quantity and area of the glacial lakes follow a gradual increment with increasing altitude, and at 4200-4500 m a.s.l, these two statistics reach their peak and then gradually decrease.

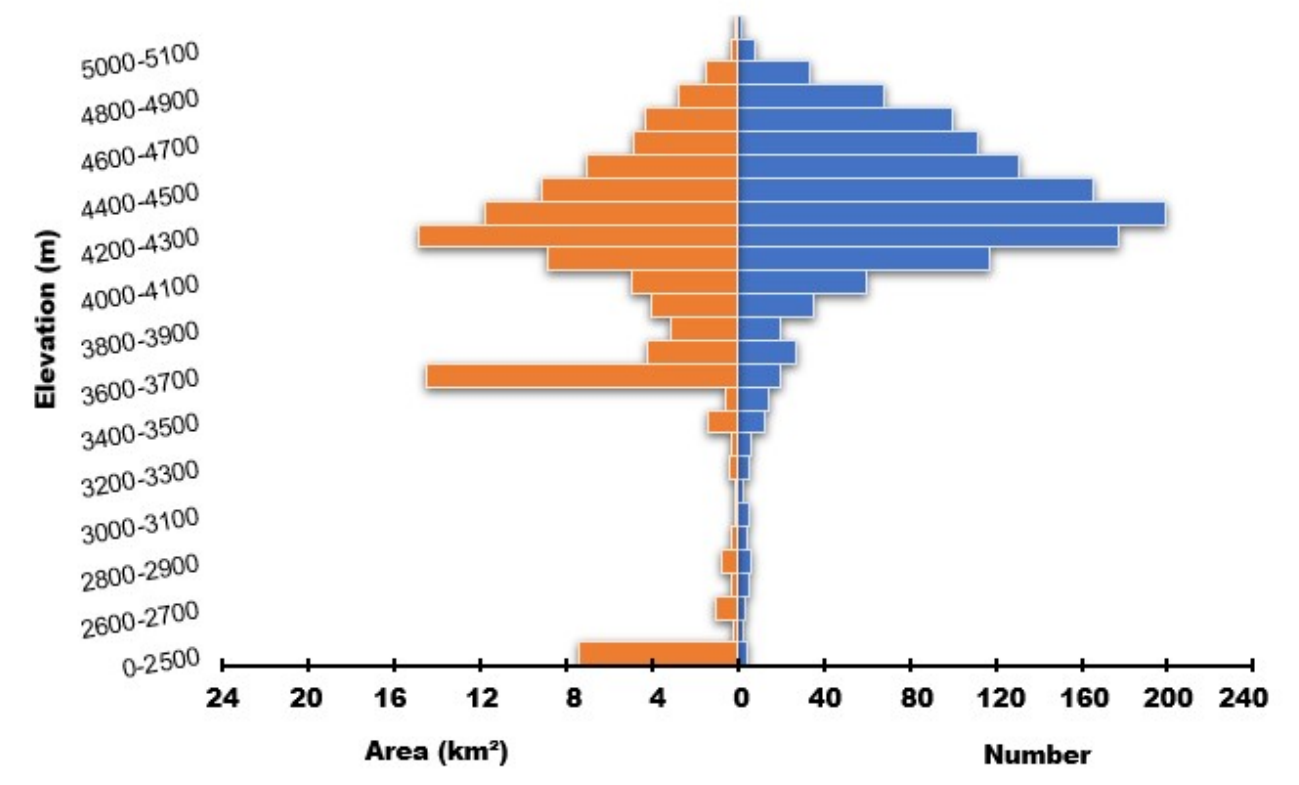

Figure 7. Glacier lake distribution at different elevations. 
Area values for particular altitude sections, such as $0-2500 \mathrm{~m}$ and $3600-3700 \mathrm{~m}$, are quite high. This is because Karakul Lake, the largest lake, is situated at $2364 \mathrm{~m}$ a.s.l., and 3 of the 10 largest lakes are located at 3600-3700 $\mathrm{m}$ a.s.l. The presence of these large lakes at low to medium altitudes creates outlier effects for specific altitude ranges. As a result, the mid-value elevation for lake area $(4218 \mathrm{~m}$ a.s.l.) is lower than that of lake number (4372 $\mathrm{m}$ a.s.l.).

The altitude distribution of glacial lakes varies widely by basin (Figure 8). Along the KKH, the mean altitudes of water basins are $4211 \mathrm{~m}$ (Gez), $4192 \mathrm{~m}$ (Taxkorgan), $4366 \mathrm{~m}$ (Hunza), $3922 \mathrm{~m}$ (Gilgit), and $3700 \mathrm{~m}$ (Indus). From Kashgar to Thakot, they first increase then decrease. The altitude distribution of almost all the glacial lakes match this variation trend. The exception is the Hunza Basin. The low distribution of glacial lakes in Hunza is caused by unique local topography: with its high mountains and deep valleys, slopes are so steep that except in the deep valleys, no developing space for glacial lakes is available. The low distribution of large valley glaciers such as the Batura glacier (its snout reaches to $2500 \mathrm{~m}$ a.s.l.) also contributes to the low distribution phenomenon seen in Hunza.

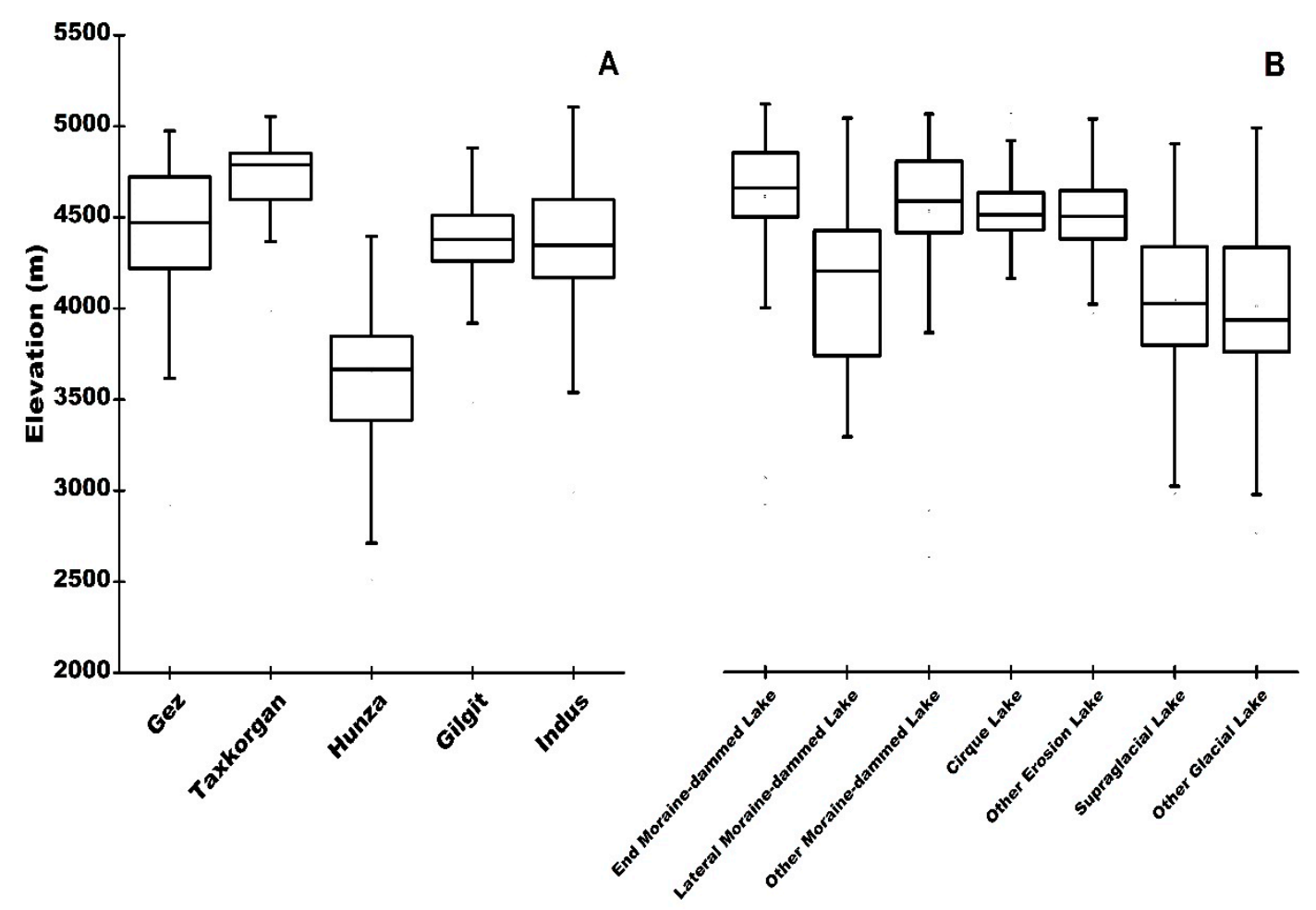

Figure 8. Glacial lake elevations in various basins (A). Glacial lake elevation by type (B).

The altitude distribution of glacial lake types differs (Figure 8). Most lakes are distributed between 4300-4500 m a.s.l. For lateral moraine-dammed, supraglacial, and other glacial lakes, large scales of altitude distribution and relatively lower average elevation (approximately $4000 \mathrm{~m}$ a.s.l.) are observed. Supraglacial lakes and lateral moraine-dammed lakes largely relate to modern and especially large glaciers such as the Batura glacier. With the large range in altitude of larger glaciers, from approximately 2500-7000 m a.s.l., supraglacial lakes and lateral moraine-dammed lakes are found in high and low altitudes. Other glacial lakes are influenced mainly by geological hazards. Geological hazards such as landslides and rockfalls block water channels, leading to the formation of other glacial lakes at every altitude.

\subsection{GLOF Evaluation}

GLOF evaluation work has been widely performed in High Mountain Asia, especially the Himalayas $[8,9,43]$. Although evaluation processes have varied by lake type, a recent study 
highlighted that end moraine-dammed lakes are more vulnerable to dam failure and subsequent GLOFs [44]. In this study, 162 end moraine-dammed lakes were delineated, and distances between these lakes and potentially threatened structures such as bridges, roads, and houses were measured. The 162 lakes were divided into four levels: almost no threat $(31-70 \mathrm{~km})$, somewhat threatening $(11-30 \mathrm{~km})$, threatening $(6-10 \mathrm{~km})$, and severely threatening $(1-5 \mathrm{~km})$. Figure 9 illustrates the distribution of end moraine-dammed lakes and their threat levels.

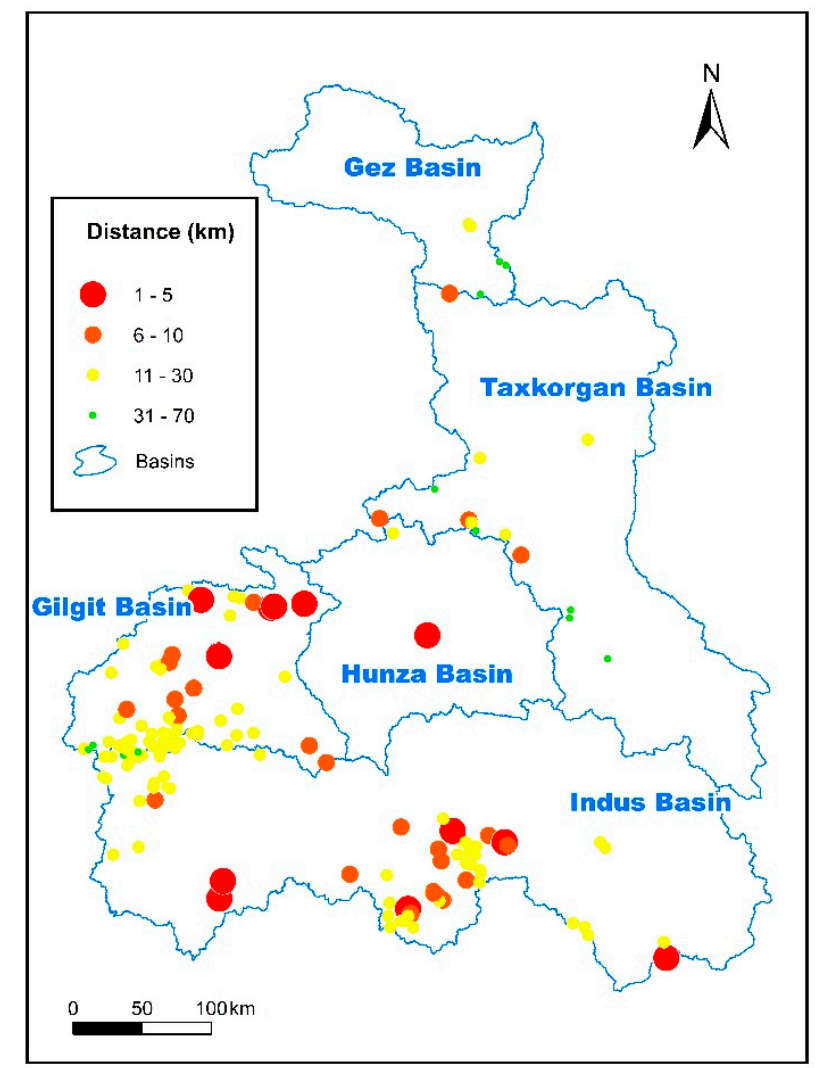

Figure 9. End moraine-dammed lakes with distances to areas sensitive to potential glacial lake outburst floods (e.g., bridges, roads, and houses).

Most end-moraine lakes (117 of 162) are at distances of more than $10 \mathrm{~km}$ from human-made structures, and we believe that these lakes would not cause considerable damage or loss to their downstream areas. Thirteen severely threatening (distances shorter than $5 \mathrm{~km}$ ) end moraine-dammed lakes are distributed in central Karakoram and the south slope of the Himalayas. Furthermore, $90 \%$ (40 of 45) of lakes at threatening or severely threatening distances are located in the Gilgit and Indus basins, putting residences and infrastructure in these basins at risk; the necessity of hazard mitigation works might be highlighted.

Relative to other lake types, 162 is not a large number; therefore, it could be concluded that few GLOFs would occur in the CPEC. However, in addition to GLOFs from moraine-dammed lakes, many GLOFs are related to geological hazards such as debris flow (classified as other glacial lakes in this study) [45] and glacier surges [46,47]. Estimating potential hazard risk through focusing on only one type of glacial lake is inadequate, and more work should be conducted on GLOF evaluation.

\section{Discussion}

Wang et al. [29] provided a systematic glacial inventory of High Mountain Asia that contains the study area of this inventory. In their inventory, 1418 glacial lakes are larger than $0.01 \mathrm{~km}^{2}$, and their total area is $85.47 \mathrm{~km}^{2}$. Although the two inventories used different glacial lake definitions 
and classification systems, they identify approximately the same number of glacial lakes. Regarding the difference in area, we included lakes more than $10 \mathrm{~km}$ from glaciers and categorized some as 'other' lakes. Briefly, this inventory can be considered credible. Compared with their study, our inventory classification is more detailed. They classified glacial lakes into two classes, glacier-fed lakes and non-glacier-fed lakes. Water resource and glacier hydrology research were highlighted. While our detailed classification aims to give more information to hazards assessment, especially GLOFs. Through lake types-based GLOFs evaluation, a practicable way might be offered to link glacial lake inventory with hazard assessment.

During classification processes, landslides are sometimes misinterpreted as having a glacial origin in the Karakoram and Himalayas [48]. Furthermore, some argue that not all cirques are of glacial origin [49]. Some lakes in this inventory may have been misclassified. Additional fieldwork and exemplar research are required.

\section{Conclusions}

Through a semiautomatic method, we employed open-access Landsat 8 OLI images to delineate glacial lakes and compile an inventory of these lakes in the CPEC. A total of 1341 lakes with an area of $109.76 \pm 9.82 \mathrm{~km}^{2}$ were identified. Lakes smaller than $0.03 \mathrm{~km}^{2}$ were predominant. Erosion lakes were the most numerous and comprised the largest area, whereas lateral moraine-dammed lakes and ice-blocked lakes were the least common. Lake spatial distribution exhibited increasing trends in both area and quantity from north to south. Nearly half of all lakes were concentrated at an elevation of $4100-4500 \mathrm{~m}$ a.s.l.

In this inventory, an attempt has been made in connecting the lake inventory and GLOF assessment through detailed classifications. It may serve as a valuable base and reference for further study.

To more fully understand glacial lakes in the CPEC, more geographical details should be collected through satellite imagery and fieldwork. Additionally, information on climate change, glacier dynamics, and glacial lake developments over decades would be invaluable. We intend to engage in case studies and hope to make the glacial lake inventory more precise.

Author Contributions: Conceptualization: Da Li and Donghui Shangguan; Methodology: Da Li; Validation: $\mathrm{Da}$ Li, Donghui Shangguan, and Muhammad Naveed Anjum; Formal Analysis: $\mathrm{Da} \mathrm{Li}$; Investigation: $\mathrm{Da} \mathrm{Li}$ and Donghui Shangguan; Data Curation: Da Li; Writing_Original Draft Preparation: Da Li; Writing-Review and Editing: Da Li, Donghui Shangguan, and Muhammad Naveed Anjum; Project Administration: Donghui Shangguan; Funding Acquisition: Donghui Shangguan. All authors have read and agreed to the published version of the manuscript.

Funding: This research was funded by the Strategic Priority Research Program of the Chinese Academy of Sciences (grant no. XDA19070502), Ministry of Science and Technology (grant no. 2018FY100502), International Partnership Program of Chinese Academy of Sciences (grant no. 131C11KYSB20160061), and National Natural Science Foundation of China (grant nos. 41950410575 and 41671066).

Acknowledgments: We wish to express sincere thanks to Prof. Jingdong Zhao for his assistance in fieldwork. Thanks to the US Geological Survey for allowing open access to Landsat images (https://glovis.usgs.gov/). This manuscript was edited by Wallace Academic Editing.

Conflicts of Interest: The authors have no conflict of interest to declare.

Data Availability: Glacial lake inventory data set is available in the attachment.

\section{References}

1. Mool, P.K. Glacial lakes and glacial lake outburst floods in the Himalayas. Nepal Geol. Soc. 2010, 110, $19-21$.

2. Hewitt, K.; Liu, J. Ice-Dammed lakes and outburst floods, Karakoram Himalaya: Historical perspectives on emerging threats. Phys. Geogr. 2010, 31, 528-551. [CrossRef]

3. Tariq, S.; Mahmood, A.; Rasul, G. Temperature and Precipitation: GLOF Triggering Indicators in Gilgit-Baltistan, Pakistan. Pakistan J. Meteorol. 2014, 10, 39-56.

4. Song, C.; Sheng, Y. Contrasting evolution patterns between glacier-fed and non-glacier-fed lakes in the Tanggula Mountains and climate cause analysis. Clim. Change 2016, 135, 493-507. [CrossRef] 
5. Wang, X.; Siegert, F.; Zhou, A.-G.; Franke, J. Glacier and glacial lake changes and their relationship in the context of climate change, Central Tibetan Plateau 1972-2010. Glob. Planet. Change 2013, 111, 246-257. [CrossRef]

6. Kääb, A.; Reynolds, J.; Haeberli, W. Glacier and Permafrost Hazards in High Mountains; Springer: Dordrecht, Netherlands, 2005.

7. Nie, Y.; Liu, Q.; Liu, S. Glacial lake expansion in the Central Himalayas by landsat images, 1990-2010. PLoS ONE 2013, 8, e83973. [CrossRef]

8. Allen, S.K.; Linsbauer, A.; Randhawa, S.S.; Huggel, C.; Rana, P.; Kumari, A. Glacial lake outburst flood risk in Himachal Pradesh, India: An integrative and anticipatory approach considering current and future threats. Nat. Hazards 2016, 84, 1741-1763. [CrossRef]

9. Haritashya, U.K.; Kargel, J.S.; Shugar, D.H.; Leonard, G.J.; Strattman, K.; Watson, C.S.; Shean, D.; Harrison, S.; Mandli, K.T.; Regmi, D. Evolution and controls of large glacial lakes in the Nepal Himalaya. Remote Sens. 2018, 10, 798. [CrossRef]

10. Zhang, G.; Yao, T.; Xie, H.; Wang, W.; Yang, W. An inventory of glacial lakes in the Third Pole region and their changes in response to global warming. Glob. Planet. Change 2015, 131, 148-157. [CrossRef]

11. Song, C.; Sheng, Y.; Wang, J.; Ke, L.; Madson, A.; Nie, Y. Heterogeneous glacial lake changes and links of lake expansions to the rapid thinning of adjacent glacier termini in the Himalayas. Geomorphology 2017, 280, 30-38. [CrossRef]

12. Khadka, N.; Zhang, G.; Thakuri, S. Glacial lakes in the Nepal Himalaya: Inventory and decadal dynamics (1977-2017). Remote Sens. 2018, 10, 1913. [CrossRef]

13. Wang, X.; Ding, Y.; Liu, S.; Jiang, L.; Wu, K.; Jiang, Z.; Guo, W. Changes of glacial lakes and implications in Tian Shan, central Asia, based on remote sensing data from 1990 to 2010. Environ. Res. Lett. 2013, 8, 44-52. [CrossRef]

14. Narama, C.; Duishonakunov, M.; Kääb, A.; Daiyrov, M.; Abdrakhmatov, K. The 24 July 2008 outburst flood at the western Zyndan glacier lake and recent regional changes in glacier lakes of the Teskey Ala-Too range, Tien Shan, Kyrgyzstan. Nat. Hazards Earth Syst. Sci. 2010, 10, 647-659. [CrossRef]

15. Richardson, S.D.; Reynolds, J.M. An overview of glacial hazards in the Himalayas. Quat. Int. 2000, 65-66, 31-47. [CrossRef]

16. Huggel, C.; Haeberli, W.; Kääb, A.; Bieri, D.; Richardson, S. An assessment procedure for glacial hazards in the Swiss Alps. Can. Geotech. J. 2004, 41, 1068-1083. [CrossRef]

17. Gardelle, J.; Berthier, E.; Arnaud, Y.; Kääb, A. Region-wide glacier mass balances over the Pamir-Karakoram-Himalaya during 1999-2011. Cryosphere 2013, 7, 1263-1286. [CrossRef]

18. Li, Y.; Ding, Y.; Shangguan, D.; Wang, R. Regional differences in global glacier retreat during climate warming from 1980 to 2015. Adv. Clim. Chang. Res. 2020. [CrossRef]

19. Quincey, D.J.; Braun, M.; Glasser, N.F.; Bishop, M.P.; Hewitt, K.; Luckman, A. Karakoram glacier surge dynamics. Geophys. Res. Lett. 2011, 38. [CrossRef]

20. Palazzi, E.; Von Hardenberg, J.; Provenzale, A. Precipitation in the hindu-kush karakoram himalaya: Observations and future scenarios. J. Geophys. Res. Atmos. 2013, 118, 85-100. [CrossRef]

21. Kapnick, S.B.; Delworth, T.L.; Ashfaq, M.; Malyshev, S.; Milly, P.C.D. Snowfall less sensitive to warming in Karakoram than in Himalayas due to a unique seasonal cycle. Nat. Geosci. 2014, 7, 834-840. [CrossRef]

22. Ahmad, I.; Zhang, F.; Tayyab, M.; Anjum, M.N.; Zaman, D.M.; Liu, J.; Farid, H.; Saddique, Q. Spatiotemporal analysis of precipitation variability in annual, seasonal and extreme values over upper Indus River basin. Atmos. Res. 2018, 213, 346-360. [CrossRef]

23. Huggel, C.; Kääb, A.; Haeberli, W.; Teysseire, P.; Paul, F. Remote sensing based assessment of hazards from glacier lake outbursts: A case study in the Swiss Alps. Can. Geotech. J. 2002, 39, 316-330. [CrossRef]

24. Mölg, N.; Bolch, T.; Rastner, P.; Strozzi, T.; Paul, F. A consistent glacier inventory for Karakoram and Pamir derived from Landsat data: Distribution of debris cover and mapping challenges. Earth Syst. Sci. Data 2018, 10, 1807-1827. [CrossRef]

25. Nuimura, T.; Sakai, A.; Taniguchi, K.; Nagai, H.; Lamsal, D.; Tsutaki, S.; Kozawa, A.; Hoshina, Y.; Takenaka, S.; Omiya, S.; et al. The GAMDAM glacier inventory: A quality-controlled inventory of Asian glaciers. Cryosphere 2015, 9, 849-864. [CrossRef]

26. McFeeters, S.K. The use of the Normalized Difference Water Index (NDWI) in the delineation of open water features. Int. J. Remote Sens. 1996, 17, 1425-1432. [CrossRef] 
27. $\mathrm{Xu}, \mathrm{H}$. Modification of normalised difference water index (NDWI) to enhance open water features in remotely sensed imagery. Int. J. Remote Sens. 2006, 27, 3025-3033. [CrossRef]

28. Raj, K.B.G.; Kumar, K.V. Inventory of Glacial Lakes and its Evolution in Uttarakhand Himalaya Using Time Series Satellite Data. J. Indian Soc. Remote Sens. 2016, 44, 959-976. [CrossRef]

29. Wang, X.; Guo, X.; Yang, C.; Liu, Q.; Wei, J.; Zhang, Y.; Liu, S.; Zhang, Y.; Jiang, Z.; Tang, Z. Glacial lake inventory of High Mountain Asia (1990-2018) derived from Landsat images. Earth Syst. Sci. Data Discuss. 2020, 1-23.

30. Rounce, D.R.; Watson, C.S.; McKinney, D.C. Identification of hazard and risk for glacial lakes in the Nepal Himalaya using satellite imagery from 2000-2015. Remote Sens. 2017, 9, 654. [CrossRef]

31. Derbyshire, E. The Karakoram and northwest Himalaya: Review and speculations. Quat. Res. 2000, 120, 147-157.

32. Allen, S.; Frey, H.; Huggel, C. GAPHAZ 2017: Assessment of Glacier and Permafrost Hazards in Mountain Regions -Technical Guidance Document; Standing Group on Glacier and Permafrost Hazards in Mountains (GAPHAZ) of the International Association of Cryospheric Sciences (IACS) and the International Permafrost Association (IPA): Zurich, Switzerland; Lima, Peru, 2017.

33. Yao, X.; Liu, S.; Han, L.; Sun, M.; Zhao, L. Definition and classification system of glacial lake for inventory and hazards study. J. Geogr. Sci. 2018, 28, 193-205. [CrossRef]

34. Nie, Y.; Sheng, Y.; Liu, Q.; Liu, L.; Liu, S.; Zhang, Y.; Song, C. A regional-scale assessment of Himalayan glacial lake changes using satellite observations from 1990 to 2015. Remote Sens. Environ. 2017, 189, 1-13. [CrossRef]

35. Wang, W.; Xiang, Y.; Gao, Y.; Lu, A.; Yao, T. Rapid expansion of glacial lakes caused by climate and glacier retreat in the Central Himalayas. Hydrol. Process. 2015, 29, 859-874. [CrossRef]

36. Narama, C.; Daiyrov, M.; Tadono, T.; Yamamoto, M.; Kääb, A.; Morita, R.; Ukita, J. Seasonal drainage of supraglacial lakes on debris-covered glaciers in the Tien Shan Mountains, Central Asia. Geomorphology 2017, 286, 133-142. [CrossRef]

37. Clague, J.J.; Evans, S.G. A review of catastrophic drainage of moraine-dammed lakes in British Columbia. Quat. Sci. Rev. 2000, 19, 1763-1783. [CrossRef]

38. Granshaw, F.D.; Fountain, A.G. Glacier change (1958-1998) in the North Cascades National Park Complex, Washington, USA. J. Glaciol. 2006, 52, 251-256. [CrossRef]

39. Hanshaw, M.N.; Bookhagen, B. Glacial areas, lake areas, and snow lines from 1975 to 2012: Status of the cordillera vilcanota, including the Quelccaya Ice Cap, northern central Andes, Peru. Cryosphere 2014, 8, 359-376. [CrossRef]

40. Bolch, T.; Menounos, B.; Wheate, R. Landsat-based inventory of glaciers in western Canada, 1985-2005. Remote Sens. Environ. 2010, 114, 127-137. [CrossRef]

41. Fujita, K.; Sakai, A.; Takenaka, S.; Nuimura, T.; Surazakov, A.B.; Sawagaki, T.; Yamanokuchi, T. Potential flood volume of Himalayan glacial lakes. Nat. Hazards Earth Syst. Sci. 2013, 13, 1827-1839. [CrossRef]

42. Fujita, K.; Sakai, A.; Nuimura, T.; Yamaguchi, S.; Sharma, R.R. Recent changes in Imja Glacial Lake and its damming moraine in the Nepal Himalaya revealed by in situ surveys and multi-temporal ASTER imagery. Environ. Res. Lett. 2009, 4, 045205. [CrossRef]

43. Allen, S.K.; Zhang, G.; Wang, W.; Yao, T.; Bolch, T. Potentially dangerous glacial lakes across the Tibetan Plateau revealed using a large-scale automated assessment approach. Sci. Bull. 2019, 64, 435-445. [CrossRef]

44. Veh, G.; Korup, O.; von Specht, S.; Roessner, S.; Walz, A. Unchanged frequency of moraine-dammed glacial lake outburst floods in the Himalaya. Nat. Clim. Chang. 2019, 9, 379-383. [CrossRef]

45. Butt, M.J.; Umar, M.; Qamar, R. Landslide dam and subsequent dam-break flood estimation using HEC-RAS model in Northern Pakistan. Nat. Hazards 2013, 65, 241-254. [CrossRef]

46. Shah, A.; Ali, K.; Nizami, S.M.; Jan, I.U.; Hussain, I.; Begum, F. Risk assessment of shishper glacier, hassanabad hunza, north pakistan. J. Himal. Earth Sci. 2019, 52, 1-11.

47. Rashid, I.; Majeed, U.; Jan, A.; Glasser, N.F. The January 2018 to September 2019 surge of Shisper Glacier, Pakistan, detected from remote sensing observations. Geomorphology 2020, 351, 106957. [CrossRef] 
48. Hewitt, K. Quaternary moraines vs. catastrophic rock avalanches in the Karakoram Himalaya, Northern Pakistan. Quat. Res. 1999, 51, 220-237. [CrossRef]

49. Turnbull, J.M.; Davies, T.R.H. A mass movement origin for cirques. Earth Surf. Process. Landf. 2006, 31, 1129-1148. [CrossRef] 